Journal of Al-Azhar University Engineering Sector

Vol. 14, No. 53,October, 2019,1481-1486

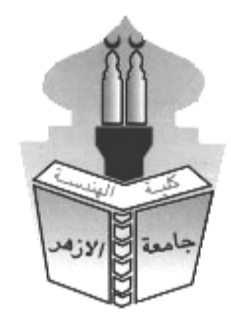

\title{
CHEMICAL AND PHYSICAL CHARACTERIZATION OF DATES PALM (PHOENIX DACTYLIFERA L) PRUNING PRODUCTS FOR THE UTILIZATION AS A RAW MATERIAL FOR MDF MANUFACTURING
}

\author{
*Omar Moneim ${ }^{1}$, Hamed El-Mously ${ }^{1}$ and Abdel-Baset A. Adam ${ }^{2}$ \\ ${ }^{1}$ Faculty of Engineering, Ain Shams University, Cairo, Egypt \\ ${ }^{2}$ Nag Hamady Fiberboard Co., Quality manger \& WBP, Egypt \\ *Corresponding author Email: omar.moneim.hassan@gmail0.com
}

\begin{abstract}
This research investigates the potentiality of using date palm pruning products (DPPP), which are midribs, fruit bunches and leaflets for production of medium-density fiberboards (MDF) and

INTRODUCTION

Medium-density fiberboards (MDF) show a growing market demand as an adequate substitute for natural wood and engineered wood products (e.g. particleboards) (De Deus, 2015)[1]. MDF properties qualify the material to be used widely in interior and exterior applications especially in furniture due to its high quality of surface due to its homogeneity and strength of fibers used in the production of the boards (Akhtar et al. 2008, Halvarsson et al. 2008)[2].With the global awareness of deforestation, more research is beingdevoted tostudy the different agricultural residues that can enrich the list of suitable raw materials for MDF manufacturing. Agricultural residues rich in fibers, and harvested with huge amounts, are grabbing attention of researchers (Abdel-Basetet al. 2014)[3].The industrial exploitation of agricultural residues will lead to the building of scientific and technological capabilities, as well as the emergence of successive waves of innovation from rural areas to urban areas of the country. Egypt has huge amounts of date palms exceeding 15 million palms, distributed among 30 governorates.
\end{abstract}

Table 1 illustrates the governorates possessing more than 1 million palms. Table 2 gives an estimation of the weights of the products of pruning of Siwi palms. Thus, it could be roughly estimated that the palms in Egypt give an additional crop of 810,000 dry tons of pruning products per year (El-Mously et al. 2016) [11]. DPPPare partially used in making crates and in roofing, while the largest percentage of those pruning products remain unused. Thus, huge amounts of DPPP are open-field burnt, causing environmental problems. It should be taken into consideration that the DPPP are seasonal materials, so they should be collected and stored in adequate quantities to ensure a long term production. MDF's production capacity has increased worldwide - especially in Asia - and has reached 100 million cubic meters in 2017 (Figure 1). 


\title{
توصيف كيميائى و فيزيقى لنواتج تقليم نخيل التمر للاستخدام كمادة خام لتصنيع ألواح ليفية متوسطة الكثافة
}

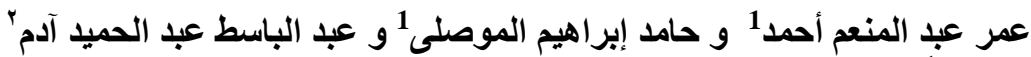

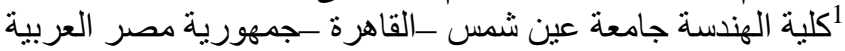

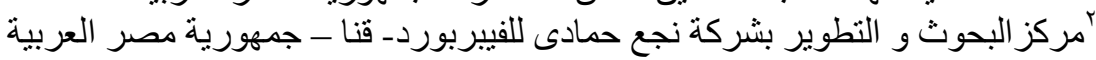

هذا البحث يتحقق من إمكانية استخدام منتجات تقليم نخيل التمر، والتي هي الجريد و العرجون و الخوص لإلتانتاج الألو اح الليفية

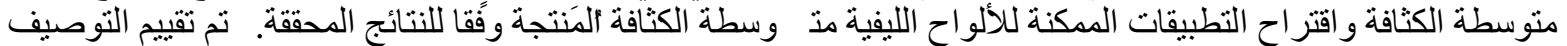

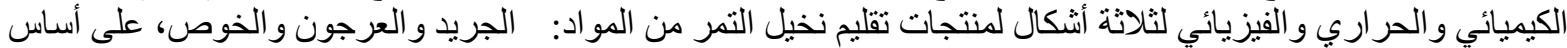

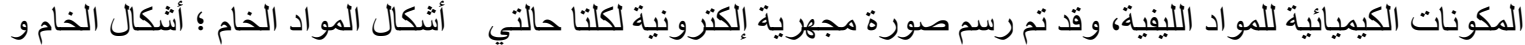

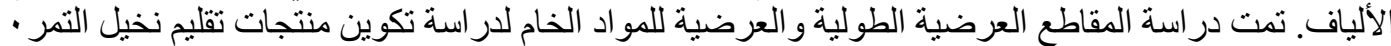

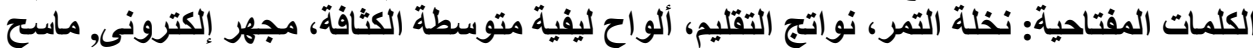

ESouthAmerica =Africa =Asia Europe northernAmerica

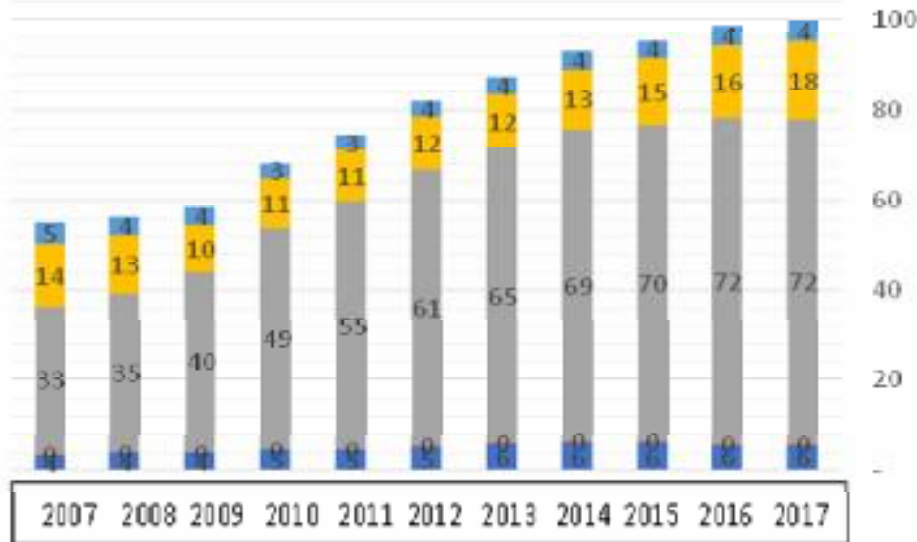

Figure 1 MDF production by continent

Table 1 Top Egyptian governorates in palms plantations

\begin{tabular}{lll}
\hline Rank & Governorate & $\begin{array}{l}\text { Amount of palms } \\
\text { (Million) }\end{array}$ \\
\hline \hline First & Aswan & $\sim 2.5$ \\
\hline Second & Giza & $\sim 1.8$ \\
\hline Third & Beheira & $\sim 1.4$ \\
\hline Fourth & New valley & $\sim 1.3$ \\
\hline Fifth & Sharqia & $\sim 1.2$ \\
\hline
\end{tabular}


CHEMICAL AND PHYSICAL CHARACTERIZATION OF DATES PALM (PHOENIX DACTYLIFERA L) PRUNING PRODUCTS FOR THE UTILIZATION AS A RAW MATERIAL FOR MDF MANUFACTURING

Table 2 Estimated weights of pruning products for each Date palm.

\begin{tabular}{lll}
\hline Parts & $\begin{array}{l}\text { Dry weight } \\
(\mathrm{Kg} .)\end{array}$ & $\begin{array}{l}\text { Residues of each palm } \\
(\%)\end{array}$ \\
\hline \hline Midribs & 15 & 28 \\
\hline Leaflets & 14.6 & 27 \\
\hline $\begin{array}{l}\text { Fruit bunches } \\
\text { stem }\end{array}$ & 9 & 17 \\
\hline Coir & 1.56 & 3 \\
\hline Midrib base & 14 & 26 \\
\hline Total & 54.16 & 100 \\
\hline
\end{tabular}

(El-Mously et al. 2016)[11]

\section{MATERIALS AND METHODS}

\section{FIBER PREPARATION AND CHARACTERIZATION}

The research focuses on the date palm pruning products specifically for the Siwi species which forms the majority of the date palms in Egypt. The pruning products have been pruned during November and December and collected from Bahariya oases, Giza governorate, Egypt. During the raw materials collection process, products have been sorted into three material groups: whole DPPP mixture (midribs, midrib base, fruit bunches, leaflets and coir), palm midribs only and fruit bunches only. In order to prepare the midribs only materials, leaflets have been removed manually by villagers. Each raw material group has been chopped separately using a drum chopper with a $2 \mathrm{~mm}$ sieve as a first processing step before further chopping in Naga Hammadi co. factory site. The fibers were continuously produced by softening the raw materials by preheating under pressure using ANDRITZ horizontal digester (Size: $10 \mathrm{~m}$, Diameter: $1 \mathrm{~m}$ and pressure: $8-8.5$ bar. At this stage, decompression occurred gradually without sudden release of pressure. The fibers were subject to 8 bars steam pressurefor 4.8 mins. After fibers preparation, they were left for air drying and moisture content was measured till it approximately reached $8 \%$.

\section{CHEMICAL ANALYSIS}

The three raw materials were prepared for chemical composition analysis by grinding samples of the materials. The tests aimed to investigate the contents of cellulose and hemicelluloses, along with the lignin and crude fibers. Samples were tested for each material using ANKOM2000 fiber analyzer. The digested fibers were subjected to a defibrator with $250 \mu \mathrm{m}$ sieve. The fibers were conditioned in labeled polyethylene bags for 12 hours to be ready for work. The chemical analysis was made to evaluate dry content of the raw materials focusing on total extractives.Extractives were determined in two-step extraction process to remove watersoluble and benzene-ethanol soluble materials, hot water extractive, ethanol-benzene extractive.

\section{SCANNING ELECTRON MICROGRAPHS}

The three raw materials were prepared to be examined by cutting thin slices of $10 \mu \mathrm{m}$ thickness using a microtome, Spencer Lens Co. The cuts were taken in the longitudinal and transverse cross sections and were investigated along with the defibrated fibers using the recording processing tools of JEOL scanning electron microscope (JSM-T3304). 
CHEMICAL AND PHYSICAL CHARACTERIZATION OF DATES PALM (PHOENIX DACTYLIFERA L) PRUNING PRODUCTS FOR THE UTILIZATION AS A RAW MATERIAL FOR MDF MANUFACTURING

\section{RESULTS AND DISCUSSION}

\section{CHARACTERIZATION OF FIBERS}

The chemical characteristics of midribs, leaves, fruit bunches and fibers are listed in Table 3 , percentages of the holocellulosecontent ranged from $(46.8974 \%)$ to $(61.3295 \%)$, percentages of alpha cellulose content from $(31.7014 \%)$ to $(38.9418 \%)$,percentages of lignin content from $(18.8831 \%)$ to $(25.4411 \%)$,percentages of pentosan content from $(15.1959 \%)$ to $(24.1949 \%)$, percentages of water extractives from $(10.0601 \%)$ to $(20.3246 \%)$,percentages of solvent extractives from $(2.3347 \%)$ to $(4.9222 \%)$, percentages of total extractives from $(12.3948 \%)$ to $(25.2468 \%)$. Thesolubility of the fibers in hot alkali $(1 \% \mathrm{NaOH}$ solubility \%) ranged from $(29.1356 \%)$ to $(55.4843 \%)$, and lastly percentages of ash contentfrom $(2.8483 \%)$ to $(5.2654 \%)$.

Table 3 Chemical characteristics of the tested DPPP fibers

\begin{tabular}{|c|c|c|c|c|c|c|c|c|c|c|}
\hline \multirow{2}{*}{ Fiber } & \multicolumn{4}{|c|}{$\begin{array}{c}\text { Extractives } \\
(\%)\end{array}$} & \multirow[b]{2}{*}{$\begin{array}{l}1 \\
\mathrm{NaOH} \\
\end{array}$} & \multirow[b]{2}{*}{ ASH\% } & \multirow[b]{2}{*}{$\mathrm{H} \%$} & \multirow[b]{2}{*}{$\mathrm{C} \%$} & \multirow[b]{2}{*}{$\mathrm{P} \%$} & \multirow[b]{2}{*}{ KL \% } \\
\hline & & Total & Water & $\begin{array}{l}\text { Ethanol- } \\
\text { benzene }\end{array}$ & & & & & & \\
\hline \multirow[t]{2}{*}{ Midribs } & Avg & 14.7489 & 11.779 & 2.9691 & 29.135 & 4.3669 & 61.329 & 37.134 & 24.194 & 18.883 \\
\hline & Std & 1.8868 & 2.0388 & 1.1284 & 2.6873 & 0.5529 & 2.2306 & 1.9676 & 1.1015 & 0.8936 \\
\hline \multirow[t]{2}{*}{ Leaflets } & $A v g$ & 25.2468 & 20.324 & 4.9222 & 55.484 & 5.2654 & 46.897 & 31.701 & 15.195 & 22.590 \\
\hline & Std & 8.7954 & 7.3552 & 1.8097 & 19.077 & 1.8815 & 15.831 & 10.650 & 5.3078 & 7.6504 \\
\hline \multirow{2}{*}{$\begin{array}{l}\text { Fruit } \\
\text { bunches }\end{array}$} & $A v g$ & 12.3948 & 10.060 & 2.3347 & 34.386 & 2.8483 & 58.631 & 38.941 & 19.690 & 25.441 \\
\hline & Std & 1.5089 & 0.7546 & 1.2540 & 3.3273 & 0.5510 & 1.8413 & 2.1844 & 1.0165 & 0.9227 \\
\hline
\end{tabular}

Avg: Average, Std: Standard deviation

According the data in Table 3 , the main components of lignocellulosicmaterial ( $\alpha$-cellulose, hemicellulose, pentosane and lignin), while holocellulose content can be arranged from the high to thelow value as midribs, fruit bunchesand leaflets respectively, alpha cellulose content can be arranged from the high to the low value as fruit bunches, midribsand leaflets respectively, pentosane content can be arranged from the high to the low value asmidribs, fruit bunches and leaflets respectively and lignin content can be arranged from the high to the low value as fruit bunches, leaflets and midribsrespectively. The percentages of the fiber extractives included the water extractives, solvent extractives and the totalextractives. The percentages of solvent extractives can be arranged from the high to the low value as leaflets, midribs, and fruit bunchesrespectively.

\section{SEM OBSERVATION OF THE TREATED FIBERS}

By using JEOL - JSM-5500 LV scanning electronic microscope, the following SEM microphotographs were taken to explainthe surface features of treated fibers. The sample was scanned without any chemical treating and it was also pretreated withsodium hydroxide $1 \%$, the best result was obtained when the sample was pretreated with sodium hydroxide $1 \%$ beforeobservation. The surface features of midrib fibers are displayed in Figure 3; M-A (500 X) explains a cross-section of midrib vessel element; M-B (2,000 X) explains a magnified view of longitudinal ray cells. The surface features of bunches fibersare displayed in Figure 4; B-A (500 $\mathrm{X}$ ) explains a cross-section of bunches vessel element; B-B $(1,000 \mathrm{X})$ explains a magnified view of longitudinal ray cells. The surface features of leaflets fibers are displayed in Figure 5; L-A $(1,000 \mathrm{X})$ is showing a cross section of one fibril which is formed from bundles of micro fibrils; L-B $(1,000 \mathrm{X})$ explains a part of ray cells. 

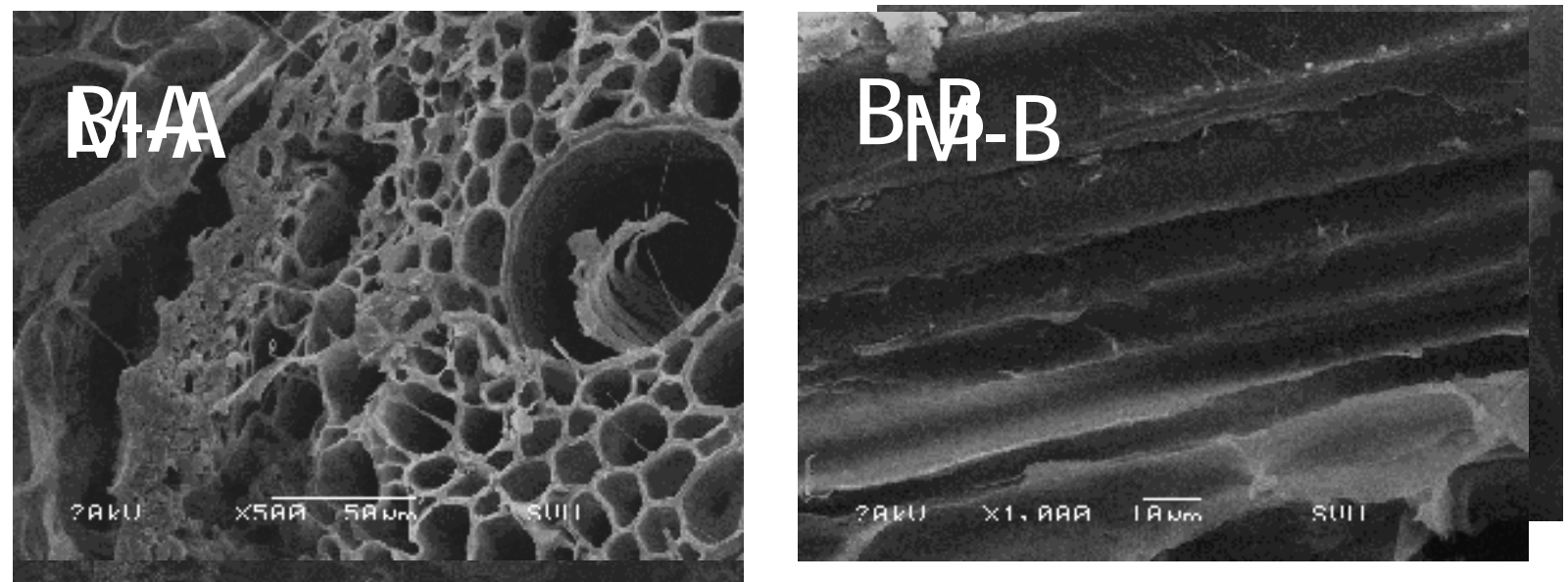

Figure 2 SEM of microphotograph of bunch fibers
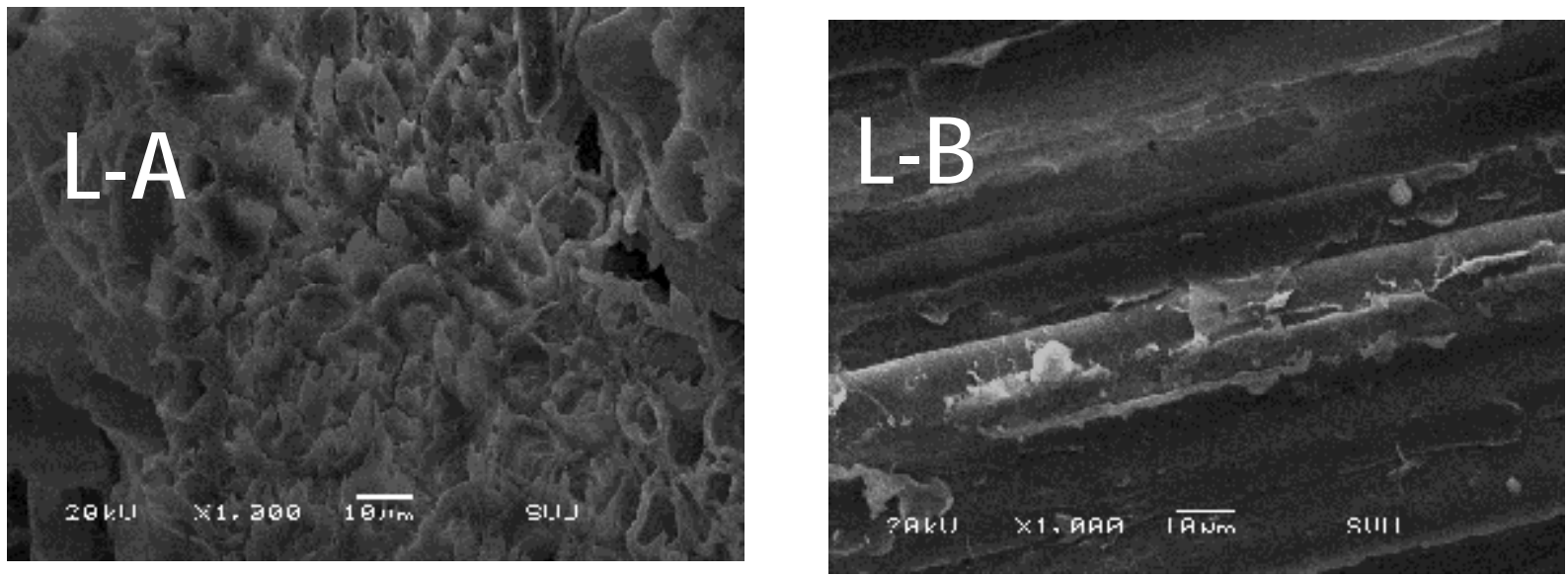

Figure 3 SEM of microphotograph of leaflets fibers

\section{EFFECT OF HOLOCELLULOSE CONTENT}

Holocellulose can be defined as the total polysaccharide fraction of the fibers or the lignocellulosic composite. It ismade up of cellulose ( $\alpha$-cellulose portion) and all of the hemicelluloses. It can be determined by removing the extractives andthe lignin content from the fibers or lignocellulosic composite. The cellulose portion is a large and wellorganizedpolysaccharides polymer. It is located in the primary cell wall, while hemicelluloses are branched polysaccharidespolymer that are less rigid than cellulose. It is made up of two monomers (pentose \& hexose) and able to wrap around thecellulose. One can guess that good mechanical properties of the manufactured panels are related to high holocelluloses content oftheir composite, but the previous statement is not always right where there are many other factors that can affect the mechanicalproperties of the manufactured panels.From the chemical properties data in Table 3 and according to the fibers holocellulose content only, one can guess that midribs $(61.329 \%)$ andfruit bunch fibers $(58.631 \%)$ have goodsuitability for manufacturing than leaflets fibers $(46.897 \%)$, i.e. they can be ordered from high to low value as midribs, fruit bunches and leaflets. 
CHEMICAL AND PHYSICAL CHARACTERIZATION OF DATES PALM (PHOENIX DACTYLIFERA L) PRUNING PRODUCTS FOR THE UTILIZATION AS A RAW MATERIAL FOR MDF MANUFACTURING

\section{CONCLUSIONS}

In the end and based on the results of this study, it can be concluded that DPPP, which are available in huge amounts all over Egypt, can be a potential materials for MDF manufacturing. Using both of midribs fibers and fruit bunches fibers for MDF manufacturing aregood solution to face the raw materials shortage in wood based panels industry. MDF manufacturing: not only contributes to reduce the shortage of raw materials but also it solves theenvironmental problems, which result from burning these pruning products. Leaflets are a lignocellulosic material that contains mild content of holocellulose $\& \alpha$-cellulose,. These lowcontents decrease the mechanical strength properties of the boards. Although leaflets fibers don't comply with the requirements of European Standards, they can be used as co-material in thecomposite to form the core layer of the particleboards or they could be used for interior purposes.

\section{ACKNOWLEDGMENT}

I would like to express my gratitude to my academic advisors, Prof. Dr. Hamed El-Mously, Dr. Abdel Baset Adam for their guidance and motivation during this research. I am extremely thankful to all the research staff in Naga Hammadi co. especially and the company administration for facilitating all the work needed and providing their help and support during this work. Also, this research would not have been possible without the collaborative efforts of people of Baharya Oasis in material collection, sorting and transportation. Lastly, I sincerely thank my family, especially my mother for her understanding and patience.

\section{REFERENCES}

1. De Deus, P. R., Alves, M. C. de S., \& Vieira, F. H. A. (2015). The quality of MDF workpieces machined in CNC milling machine in cutting speeds, feedrate, and depth of cut. Meccanica, 50(12), 2899-2906. https://doi.org/10.1007/s11012-015-0187-z

2. Akhtar, M., Kenealy, W. R., Horn, E. G., Swaney, R. E. and Winandy, J. E. (2008) Method of making medium density fiberboard. US Patent No: US 2008/0264588 A1.

3. Adam, A.-B. A., Basta, A. H., El-Saied, H., \& Soliman, M. K. (2014b). Sesbania aegyptiacaas promising biomass for manufacturing of MDF. Wood Material Science \& Engineering, 9(1), 49-57. https://doi.org/10.1080/17480272.2013.869255

4. Ye, X. Philip; Julson, James; Kuo, Monlin; Al Womac ; Myers, Deland. (2007). Properties of medium density fiberboards made from renewable biomass. Bioresource Technology 98:1077-1084.

5. Halvarsson, Soren; Edlund, Hakan and Norgren, Magnus. (2010). Fiberboard from wheat straw. BioResources Technology 5(2):1215-1231.

6. American Society for Testing and Materials. (Reapproved 2007). Standard test method for ash content in wood and wood-based materials. Philadelphia, USA. ASTM D1102-84. Available at: www.astm.org

7. National Renewable Energy Laboratory. (2008). Determination of Extractives in Biomass NREL, Technical Report, USA. NREL/TP-510-42619: Website: http: //www.nrel.gov

8. Technical Association of Pulp and Paper Industry. (2002). T $212 \mathrm{~cm}-02$.One percent sodium hydroxide solubility of wood and pulp., USA. (n.d.). doi: https://research.cnr.ncsu.edu/wpsanalytical/documents/T212.PDF

9. Technical Association of Pulp and Paper Industry. (2008). T $207 \mathrm{~cm}-08$. Water solubility of wood and pulp paper extracts., USA. (n.d.). doi: https://research.cnr.ncsu.edu/wpsanalytical/documents/T207.PDF

10. Technical Association of Pulp and Paper Industry. (2002). T 222 om-11. Acid-insoluble lignin in wood and pulp. USA. (n.d.). doi: https://research.cnr.ncsu.edu/wpsanalytical/documents/T222.PDF

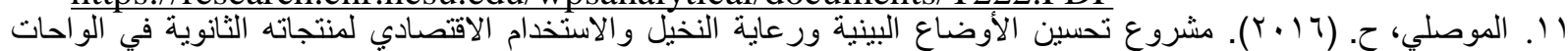
البحرية، التقرير النهائي. مصر، القاهرة. وزارة البيئة. الثانوية في الواحاتية الثات البحرية، النقرير النهائي. 